\title{
Heavy metal accumulation and calcium content in the bivalve Donacilla cornea
}

\author{
Francesco Regoli ${ }^{1}$, Enzo Orlando ${ }^{1}$, Marina Mauri ${ }^{2}$, Marco Nigro $^{1}$, \\ Giulia Alfinito Cognetti ${ }^{1}$ \\ ${ }^{1}$ Dipartimento di Biomedicina Sperimentale Infettiva e Pubblica, Università di Pisa, Via Volta 4, I-56100 Pisa, Italy \\ ${ }^{2}$ Dipartimento di Biologia Animale, Università di Modena, Via Università 4, I-41100 Modena, Italy
}

\begin{abstract}
Accumulation of heavy metals ( $\mathrm{Cu}, \mathrm{Cd}$ and $\mathrm{Mn}$ ) and their effects on total Ca content were studied under laboratory conditions in sandy-bottom bivalves Donacilla cornea from an unpolluted shore in northern Sardinia. The bivalves were found to accumulate the 3 metals. Exposure at 2 different temperatures $\left(18\right.$ and $25^{\circ} \mathrm{C}$ ) showed significant differences only for $\mathrm{Cu}$ accumulation. Following decontamination in clean seawater, the body content of $\mathrm{Cu}$ and $\mathrm{Mn}$ decreased strongly, whereas that of $\mathrm{Cd}$ remained practically unchanged. Among organs, gills contained the highest metal concentrations. A net increase of total $\mathrm{Ca}$ concentration in the body was observed during metal accumulation, and the digestive gland seems the most suitable organ for studies on the effects of heavy metals on calcium homeostasis.
\end{abstract}

\section{INTRODUCTION}

Marine bivalves are known to accumulate and tolerate high concentrations of heavy metals (Graham 1972. Windom \& Smith 1972, Alexander \& Young 1976, Okazaki 1976, Goldberg 1980). Therefore they have been used as monitors of pollution of the marine environment (Goldberg 1986). Moreover, some species are widely employed in laboratory studies on uptake, loss and biological effects of heavy metals, petroleum compounds and other chemicals (Bayne 1980, Widdows et al. 1981. Bayne et al. 1982). Although heavy metals are known to interfere with calcium homeostasis in mammals and fishes (Ma et al. 1974. Shephard \& Simkiss 1978, Bansal et al. 1985, Reddy et al. 1988, Zhang et al. 1990), very few data are available for marine invertebrates (Viarengo et al. 1988a, b).

In this study we investigated the ability of the seawedge shell Donacilla cornea (Poli) to concentrate copper, cadmium and manganese and the effect of these heavy metals on total calcium content in gills, digestive gland and whole soft parts.

\section{MATERIAL AND METHODS}

Donacilla cornea $(1.5 \pm 0.5 \mathrm{~cm}$ shell length $)$ were collected in April 1989 from Porto Pozzo, an unpolluted sandy shore in northern Sardinia. The bivalves were acclimatized for $7 \mathrm{~d}$ in synthetic aerated seawater $(37 \%$ salinity) without sediment before exposure to $\mathrm{Cu}, \mathrm{Cd}$ and $\mathrm{Mn}$, supplied separately.

Metal exposures were carried out at 18 and $25^{\circ} \mathrm{C}$. Concentrations of $\mathrm{Cu}$ in seawater were 150 and $300 \mu \mathrm{g}$ $\mathrm{l}^{-1}$ at $18^{\circ} \mathrm{C}$ and 100 and $150 \mu \mathrm{g} \mathrm{l^{-1 }}$ at $25^{\circ} \mathrm{C}$. At this latter temperature levels of $\mathrm{Cu}$ in seawater higher than $150 \mathrm{\mu g} \mathrm{l}^{-1}$ resulted in a too high mortality. Cd and $\mathrm{Mn}$ concentrations were respectively $200 \mu \mathrm{gl}^{-1}$ and $10 \mathrm{mg}$ $1^{-1}$ at both temperatures. The concentration of Mn used in this work was in the range of values measured in interstitial waters of the estuarine area of the Arno river, Italy (Mauri \& Orlando 1982). Seawater (0.5 1 ind ${ }^{-1}$ ) was changed daily and specimens were not fed during the experiments. Bivalves were supplied with heavy metals and then allowed to depurate in clean seawater.

For each treatment 15 individuals were sampled at different times and groups of 3 were used for metal analysis. The entire soft parts, separated from the shells, were weighed wet and dry and then digested with nitric acid (Aristar BDH) in closed teflon vessels, first at room temperature for $8 \mathrm{~h}$ and then at $120^{\circ} \mathrm{C}$ for $10.5 \mathrm{~h}$. The analytical procedure was checked with standard reference material (lobster hepatopancreas) provided by the National Research Council of Canada.

Bivalves exposed at $18^{\circ} \mathrm{C}$ to $\mathrm{Cu}\left(150 \mu \mathrm{g} \mathrm{l}^{-1}\right), \mathrm{Cd}(200$ $\left.\mu \mathrm{g}^{-1}\right)$ and $\mathrm{Mn}\left(10 \mathrm{mg} \mathrm{l}^{-1}\right)$ were also used for measur- 
ing concentrations of $\mathrm{Ca}$ in digestive gland, gills and total soft parts. Some bivalves were exposed to metals for $14 \mathrm{~d}_{i}$ others were transferred to clean seawater after $7 \mathrm{~d}$ of exposure. Samples were collected after 7 and $14 \mathrm{~d}$. Each sample consisted of 25 individuals: the organs, dissected from these specimens, were grouped into 5 pools, rinsed in a Ca-free physiological solution, and weighed before acid digestion.

Metals were determined by flame atomic absorption spectrophotometer (IL mod. S11 equipped with deuterium background corrector). Lanthanum nitrate $(0.1 \%)$ was added before $\mathrm{Ca}$ determination to control chemical and ionization interferences. The differences between groups of means were tested firstly with the analysis of variance (ANOVA) and then with the multiple range test of Scheffe.

\section{RESULTS}

\section{Accumulation of heavy metals}

Laboratory experiments revealed that copper was strongly accumulated by Donacilla cornea (Fig. 1), with maximum body concentrations at $25^{\circ} \mathrm{C}$. At this temperature the body concentrations for $150 \mathrm{\mu g} \mathrm{l^{-1 }}$ of $\mathrm{Cu}$ in seawater were significantly higher than for $100 \mu \mathrm{I}^{-1}$. No significant differences in $\mathrm{Cu}$ accumulation were observed at $18^{\circ} \mathrm{C}$ between individuals exposed to 150 and $300 \mu \mathrm{g} \mathrm{Cu} \mathrm{l}^{-1}$. Loss of $\mathrm{Cu}$ occurred when exposed individuals were transferred to clean seawater. After $6 \mathrm{~d}$ of decontamination, $\mathrm{Cu}$ decreased by about $50 \%$, and at the 15 th day values similar to those found in controls were measured (Fig. 1).

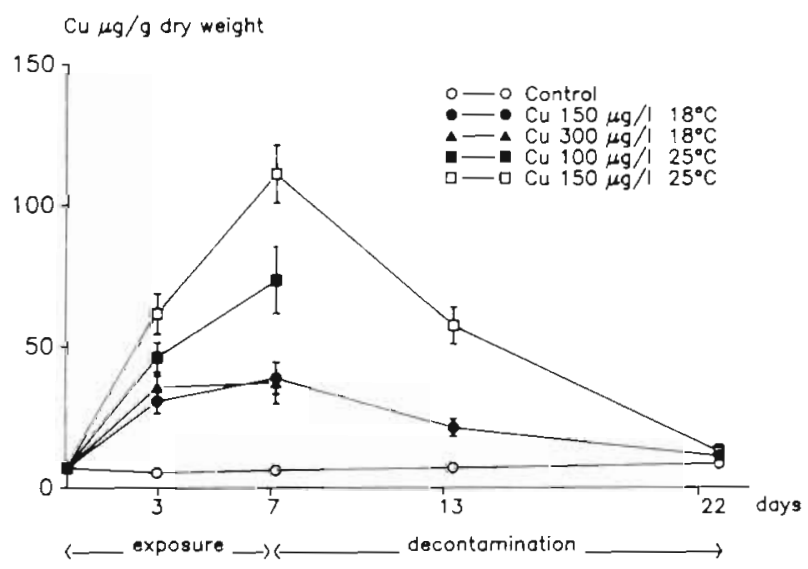

Fig. 1. Donacilla cornea. Copper concentrations (means of 5 samples $\pm S D$ ) in the total soft parts of bivalves exposed to $\mathrm{Cu}$ and allowed to decontaminate in clean seawater at 18 and $25^{\circ} \mathrm{C}$ for $15 \mathrm{~d}$
No differences in cadmium and manganese accumulation were observed between 18 and $25^{\circ} \mathrm{C}$. Cd concentration progressively increased throughout the period of exposure. After $15 \mathrm{~d}$ in clean seawater, the loss of the metal was not statistically significant (Fig. 2). Mn was rapidly accumulated, the whole-body concentration reaching a maximum at the 3rd day and then remaining almost constant (Fig. 3). Following $3 \mathrm{~d}$ in clean seawater the decrease of the metal was $60 \%$. However control organisms also showed a significant loss of $\mathrm{Mn}$ with a decrease of about $50 \%$ after $13 \mathrm{~d}$.

Data on the content of heavy metals in the organs (Tables 1 to 3) showed the highest concentrations of $\mathrm{Cu}, \mathrm{Cd}$ and $\mathrm{Mn}$ in the gills in which, following decontamination, an important loss of these 3 metals was observed. Decontamination did not significantly

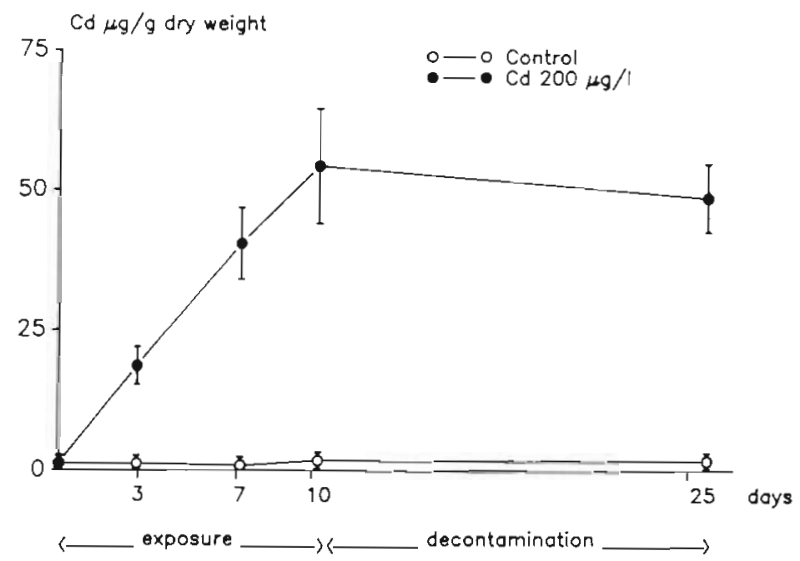

Fig. 2. Donacilla cornea. Cadmium concentrations (means of 10 samples $\ldots \mathrm{SD}$ ) in the total soft parts of bivalves exposed to $\mathrm{Cd}$ and allowed to decontaminate in clean seawater for $15 \mathrm{~d}$

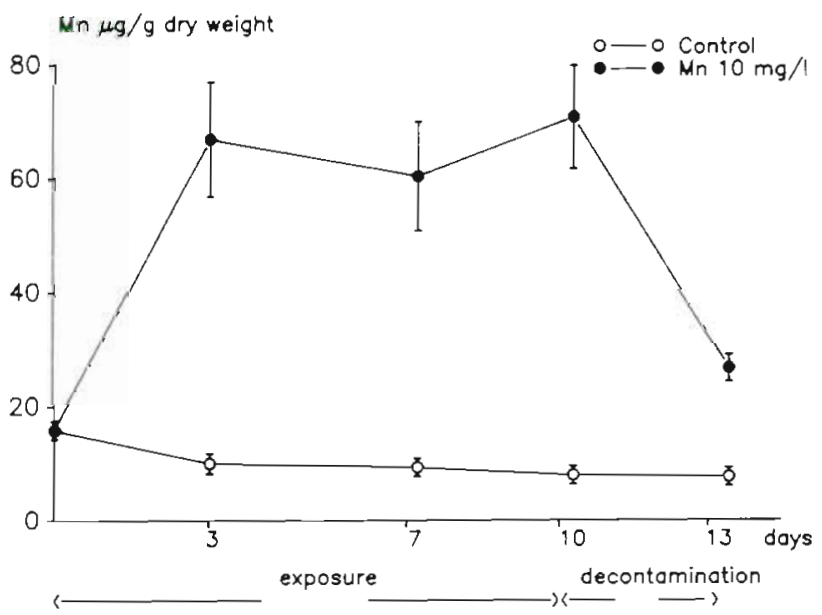

Fig. 3. Donacilla cornea. Manganese concentrations (means of 10 samples $\pm S D$ ) in the total soft parts of bivalves exposed to $\mathrm{Mn}$ and allowed to decontaminate in clean seawater for $3 \mathrm{~d}$ 
change the concentrations of $\mathrm{Cu}$ and $\mathrm{Cd}$ in the digestive gland, whereas $\mathrm{Mn}$ levels here returned to control values after $7 \mathrm{~d}$ in clean seawater.

\section{Variations of total calcium content}

No significant differences in calcium levels were observed in controls during the experiment, whereas in general a net increase of the metal was observed in the total soft parts and in the organs of Donacilla cornea exposed to heavy metals (Tables 1 to 3 ).

In whole individuals (Tables 1 \& 2) large increases in Ca concentrations were observed following exposure to $\mathrm{Cu}(+89.8 \%$ after $7 \mathrm{~d})$ and to $\mathrm{Cd}(+252 \%$ after $14 \mathrm{~d})$. Similarly, in the digestive gland, exposure to heavy metals significantly increased the $\mathrm{Ca}$ concentration (Tables 1 to 3 ). In individuals exposed to $\mathrm{Cu}$ or $\mathrm{Cd}$ this organ did not lose Ca (Figs. $4 b$ \& 5b), nor heavy metals (Figs. 4a \& 5a), after $7 \mathrm{~d}$ decontamination. On the contrary a net decrease of Ca (Fig. 6b) accompanied the loss of Mn (Fig. 6a).

In bivalves exposed to the 3 metals separately, the gills showed Ca increases which, when significant, were smaller than those observed in total soft parts or in the digestive gland (Tables 1 to 3 ).

\section{DISCUSSION AND CONCLUSIONS}

From our results it appears clearly that Donacilla cornea is able to accumulate copper, cadmium and

Table 1. Donacilla cornea. Mean values and standard deviations $(\mathrm{n}=5)$ for $\mathrm{Cu}$ and $\mathrm{Ca}\left(\mu \mathrm{g} \mathrm{g} \mathrm{g}^{-1}\right.$ dry wt) in the digestive gland, gills and total soft parts of bivalves exposed to $\mathrm{Cu}\left(150 \mu \mathrm{g} \mathrm{l}^{-1}, 18^{\circ} \mathrm{C}\right)$. Also shown are percentage variations of Ca and significance with respect to the mean value at Day $0\left({ }^{*} p>0.05 ; \cdots p<0.05\right)$. Exp.: days of exposure to the metal; Decon.: days of decontamination in clean seawater

\begin{tabular}{|c|c|c|c|c|c|}
\hline Exp. & (d) Decon. & Body part & $\mathrm{Cu}$ & $\mathrm{Ca}$ & $\mathrm{Ca} \%$ \\
\hline 0 & - & Dig. gland & $16.2 \pm 1.8$ & $960 \pm 100$ & - \\
\hline 0 & - & Gills & $22.5 \pm 3.2$ & $1240 \pm 190$ & - \\
\hline 0 & - & Soft parts & $7.1 \pm 1.6$ & $1080 \pm 180$ & - \\
\hline 7 & - & Dig gland & $38.2 \pm 3.9$ & $1200 \pm 140$ & $+25.0^{\circ}$ \\
\hline 7 & - & Gills & $64.2 \pm 8.5$ & $1520 \pm 100$ & $+22.6^{\cdots}$ \\
\hline 7 & - & Soft parts & $38.8 \pm 5.7$ & $2050 \pm 150$ & $+89.8^{*}$ \\
\hline 14 & - & Dig. gland & $61.3 \pm 7.8$ & $2300 \pm 220$ & $+139 \cdots$ \\
\hline 14 & - & Gills & $120 \pm 15$ & $1430 \pm 80$ & $+15.3^{\circ}$ \\
\hline 14 & - & Soft parts & $68.1 \pm 5.7$ & $1670 \pm 110$ & $+54.6^{\circ}$ \\
\hline 7 & 7 & Dig. gland & $40.2 \pm 3.5$ & $1340 \pm 80$ & $+39.6 *$ \\
\hline 7 & 7 & Gills & $36.2 \pm 3.3$ & $1100 \pm 100$ & $-11.3^{\circ}$ \\
\hline 7 & 7 & Soft parts & $22.8 \pm 3.7$ & $1260 \pm 200$ & $+16.7^{\circ}$ \\
\hline
\end{tabular}

Table 2. Donacilla cornea. Mean values and standard deviations $(\mathrm{n}=5)$ for $\mathrm{Cd}$ and $\mathrm{Ca}\left(\mathrm{ug} \mathrm{g}^{-1} \mathrm{dry}\right.$ wt) in the digestive gland, gills and total soft parts of bivalves exposed to $\mathrm{Cd}\left(200 \mu \mathrm{g} \mathrm{l} \mathrm{l}^{-1}, 18^{\circ} \mathrm{C}\right)$. See Table 1 for explanation

\begin{tabular}{|c|c|c|c|c|c|}
\hline Exp. & $\begin{array}{l}\text { Decon. } \\
\text { (d) }\end{array}$ & Body part & $\mathrm{Cd}$ & $\mathrm{Ca}$ & $\mathrm{Ca} \%$ \\
\hline 0 & - & Dig. gland & $1.0 \pm 0.2$ & $960 \pm 100$ & - \\
\hline 0 & - & Gills & $2.3 \pm 0.3$ & $1240 \pm 190$ & - \\
\hline 0 & - & Soft parts & $1.2 \pm 0.2$ & $1080 \pm 180$ & - \\
\hline 7 & - & Dig. gland & $33.2 \pm 5.9$ & $1190 \pm 180$ & $+240^{\circ}$ \\
\hline 7 & - & Gills & $56.7 \pm 5.5$ & $1300 \pm 190$ & $+4.8^{\circ}$ \\
\hline 7 & - & Soft parts & $40.4 \pm 6.4$ & $2130 \pm 290$ & $+97.2 \cdots$ \\
\hline 14 & - & Dig. gland & $57.3 \pm 10.3$ & $1370 \pm 160$ & $+43.1 \cdots$ \\
\hline 14 & - & Gills & $105 \pm 20$ & $1670 \pm 140$ & $+34.8^{\circ}$ \\
\hline 14 & - & Soft parts & $73.5 \pm 13.6$ & $3800 \pm 510$ & $+252 \cdots$ \\
\hline 7 & 7 & Dig. gland & $35.1 \pm 6.3$ & $1270 \pm 210$ & $+32.3 \cdots$ \\
\hline 7 & 7 & Gills & $34.8 \pm 6.2$ & $1290 \pm 70$ & $+4.0^{\circ}$ \\
\hline 7 & 7 & Soft parts & $37.4 \pm 6.9$ & $2350 \pm 420$ & $+118 \cdots$ \\
\hline
\end{tabular}


Table 3. Donacilla cornea. Mean values and standard deviations $(\mathrm{n}=5)$ for $\mathrm{Mn}$ and $\mathrm{Ca}\left(\mu \mathrm{g} \mathrm{g}^{-1} \mathrm{dry}\right.$ wt) in the digestive gland and gills of bivalves exposed to $\mathrm{Mn}\left(10 \mathrm{mg} \mathrm{1^{-1 }}, 18^{\circ} \mathrm{C}\right)$. See Table 1 for explanation

\begin{tabular}{|c|c|c|c|c|c|}
\hline Exp. & (d) Decon. & Body part & $\mathrm{Mn}$ & $\mathrm{Ca}$ & $\mathrm{Ca} \%$ \\
\hline 0 & -- & Dig gland & $7.9 \pm 1.4$ & $960 \pm 100$ & - \\
\hline 0 & - & Gills & $7.0 \pm 0.9$ & $1240 \pm 190$ & - \\
\hline 7 & - & Dig. gland & $25.7 \pm 2.6$ & $2370 \pm 310$ & $+147 \quad \cdots$ \\
\hline 7 & - & Gills & $46.7 \pm 8.3$ & $1320 \pm 130$ & $+6.5^{\circ}$ \\
\hline 7 & 7 & Dig gland & $6.1 \pm 1.1$ & $1030 \pm 130$ & $+7.3^{\circ}$ \\
\hline 7 & 7 & Gills & $7.1 \pm 0.9$ & $1490 \pm 120$ & $+20.2^{\circ}$ \\
\hline
\end{tabular}
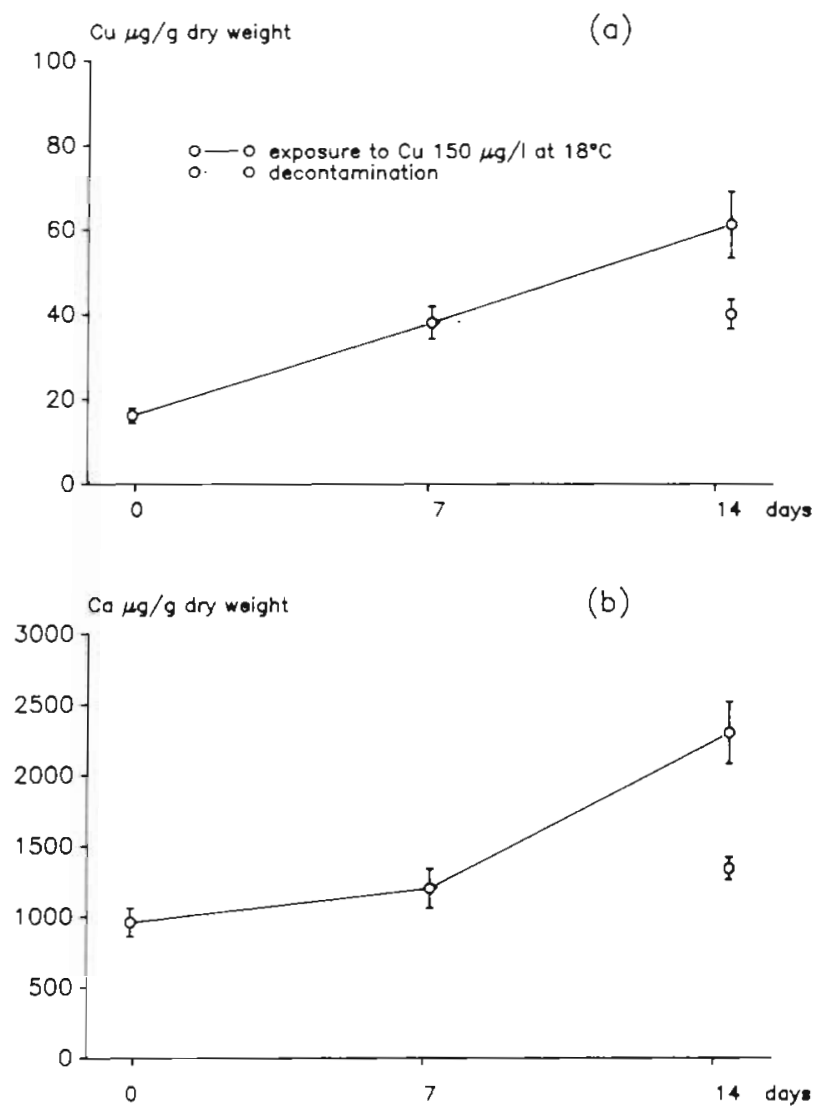

Fig. 4. Donacilla cornea. (a) Copper and (b) calcium concentrations (means of 5 samples $\pm \mathrm{SD}$ ) in the digestive gland of bivalves exposed to $\mathrm{Cu}\left(150 \mathrm{ug} \mathrm{l}^{-1}\right.$ at $\left.18^{\circ} \mathrm{C}\right)$ and allowed to decontaminate in clean seawater for $7 \mathrm{~d}$

manganese, with the highest concentrations occurring in the gills.

Temperature does not seem to affect $\mathrm{Cd}$ and $\mathrm{Mn}$ uptake in Donacilla cornea, but copper concentrations were significantly higher at $25^{\circ} \mathrm{C}$ than at $18^{\circ} \mathrm{C}$. In contrast, in the gills of Mytilus galloprovincialis accumulation of $\mathrm{Cu}$ at $13^{\circ} \mathrm{C}$ was higher than at $23^{\circ}$ (Viarengo et al. 1988b). Moreover it was reported that Cd uptake in Mytilus edulis was affected by tempera-
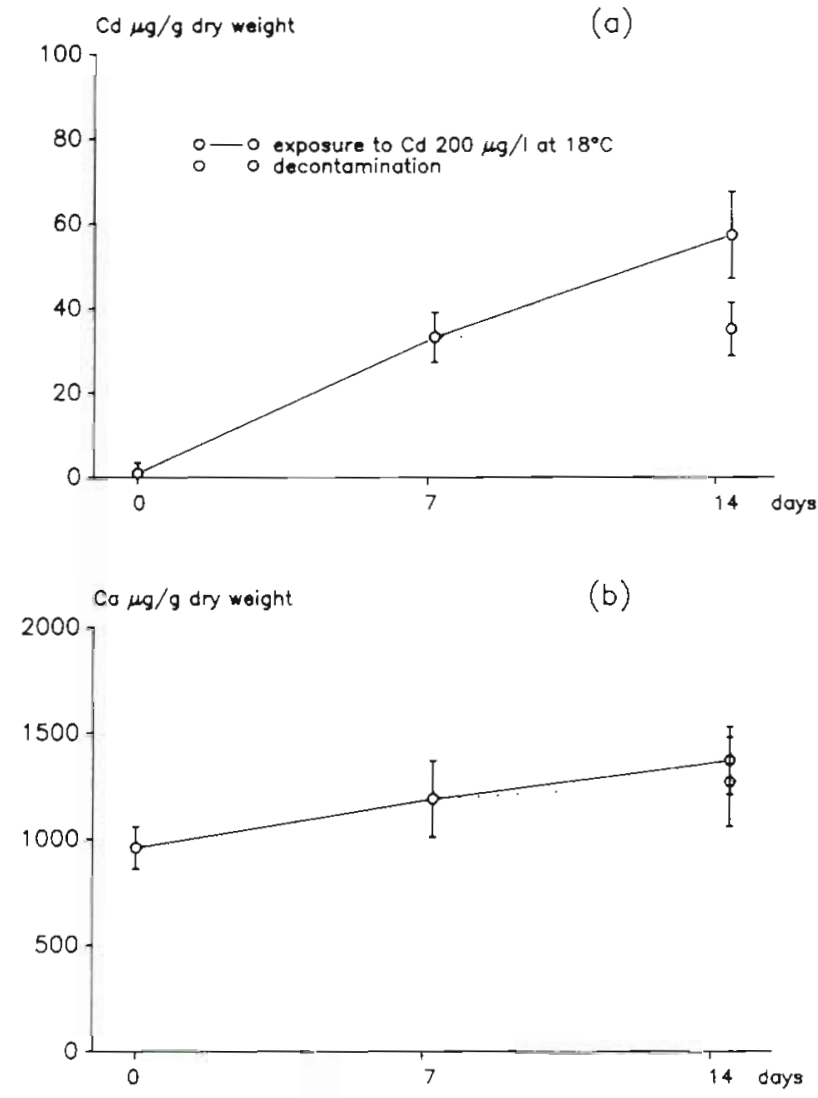

Fig. 5. Donacilla cornea. (a) Cadmium and (b) calcium concentrations (means of 5 samples $\pm \mathrm{SD}$ ) in the digestive gland of bivalves exposed to $\mathrm{Cd}\left(200 \mu \mathrm{g} \mathrm{l^{-1 }}\right.$ at $\left.18^{\circ} \mathrm{C}\right)$ and allowed to decontaminate in clean seawater for $7 \mathrm{~d}$

ture only at low (12\%) salinity (Phillips 1976). According to the latter author, temperature influences $\mathrm{Cu}$ accumulation causing variations in either uptake or excretion of the metal, often leading to erratic results.

Since our experiments were carried out in the $a b$ sence of food and sediments, the accumulation of heavy metals probably occurred via a direct uptake mechanism from water. Our findings do not exclude that bacteria, introduced with the bivalves, might influ- 

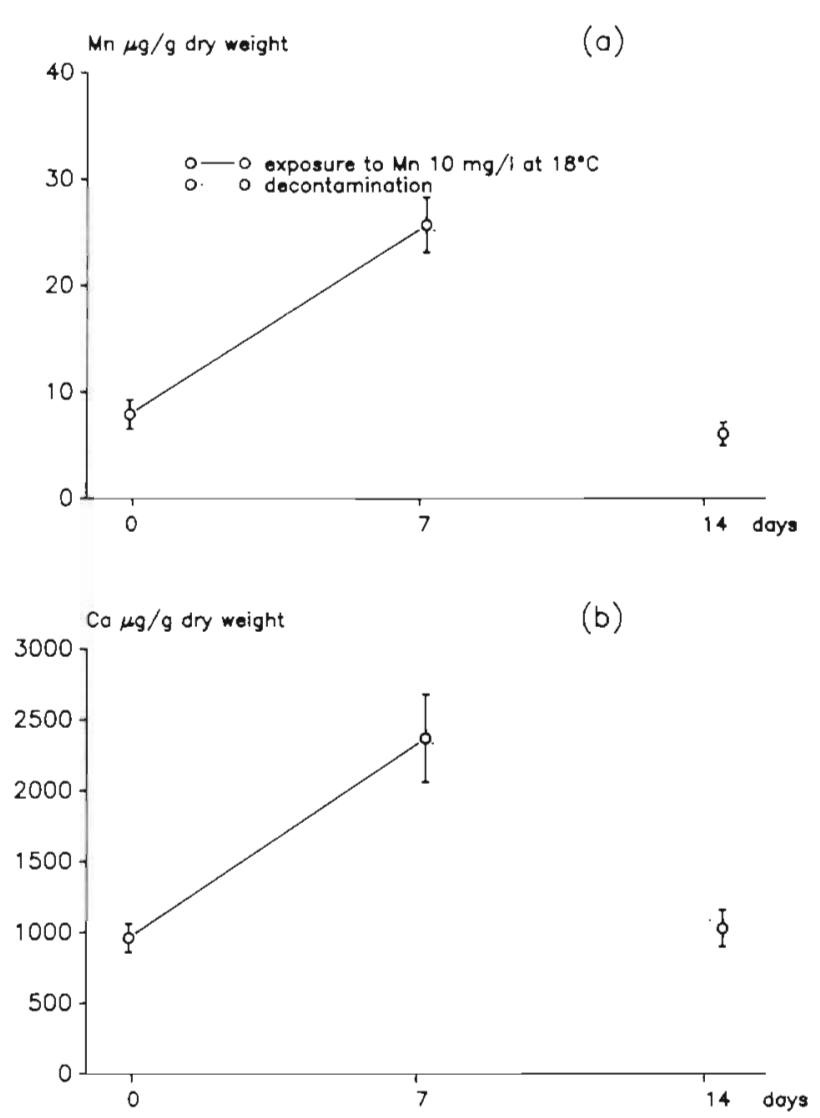

Fig. 6. Donacilla cornea. (a) Manganese and (b) calcium concentrations (means of 5 samples $\pm \mathrm{SD}$ ) in the digestive gland of bivalves exposed to $\mathrm{Mn}\left(10 \mathrm{mg} \mathrm{l} \mathrm{I}^{-1}\right.$ at $\left.18^{\circ} \mathrm{C}\right)$ and allowed to decontaminate in clean seawater for $7 \mathrm{~d}$

ence heavy metal uptake. This aspect should be investigated in future studies.

Following decontamination whole-body $\mathrm{Cu}$ levels lowered to control values, whereas total Cd decrease was not statistically significant. This result might be related to the different capacity of the cells to eliminate these 2 metals, when they are bound to thioneins (Viarengo et al. 1985). In fact, in another bivalve (Mytilus galloprovincialis), $\mathrm{Cu}$ bound to thioneins was accumulated within the lysosomal system and then eliminated by exocitosis of the residual bodies (Viarengo et al. 1984). For Cd, such a mechanism does not seem to occur: only a small percentage of this metal was eliminated by excretion of residual bodies, probably bound to the peroxidated lysosomal matrix (George 1983a, b). Considering that the gills lost $38 \%$ of $\mathrm{Cd}$ following decontamination, it might be speculated that only part of the metal found in this organ was bound to metallothioneins. Practically no loss of $\mathrm{Cu}$ was observed in the digestive gland after a $7 \mathrm{~d}$ recovery in clean seawater. This suggests that $\mathrm{Cu}$ is firmly bound and that depuration of this metal requires a longer period of time. Pringle et al. (1968) suggested that the depletion rate from a tissue is directly related to metal concentration. Likewise. Schulz-Baldes (1974) reported that in Mytilus edulis the loss of lead was closely correlated with the internal metal concentration.

The marked and fast loss of Mn following decontamination of Donacilla cornea, and observed also in control organisms, is probably due to metal unbound or loosely bound in the tissues. In this respect, it is of interest to note that Bryan \& Hummerstone (1973) found rapid Mn depletion in the polychaete Nereis diversicolor.

The sharp increases in Ca levels observed in bivalves exposed to heavy metals, but not in the controls, indicate an alteration of $\mathrm{Ca}$ homeostasis as a result of heavy metals accumulation. A significant increase of total $\mathrm{Ca}$ content was also found in the gills of mussels exposed to Cu (Viarengo et al. 1988b) and in the digestive gland after exposure to $\mathrm{Cu}$ in presence of hydrocarbons (Viarengo et al. 1988a). The pattern of Ca variations in the digestive gland were rather similar to those of the heavy metals (Figs. 4 to 6 ).

The increases in Ca concentrations in whole organisms exposed to $\mathrm{Cu}$ or to $\mathrm{Cd}$, much larger than those observed in some organs, probably reflect the high content of $\mathrm{Ca}$ in the kidney, where numerous granules containing Ca phosphate were found to accumulate in renal cells during exposure to metals (authors unpubl.).

From our results, it appears that, while the gills of Donacilla cornea are good material for monitoring heavy metals in seawater, its digestive gland is particularly suitable for studies on the effect of heavy metals on Ca homeostasis.

Acknowledgements. We thank Prof. S. Bonotto for fruitful discussions.

\section{LITERATURE CITED}

Alexander, G. V., Young, D. R. (1976). Trace metals in Southern California mussels. Mar. Pollut. Bull. 7: 228-231

Bansal, S. K., Murthy, R. C., Chandra, S. V. (1985). The effects of some divalent metals on cardiac and branchial $\mathrm{Ca}^{2+}$ ATPase in a freshwater fish Saccobranchus fossilis. Ecotoxicol. Environ. Safety 9: 373-377

Bayne, B. L. (1980). Physiological measurements of stress. Rapp. P.-v. Réun. Cons. int. Explor. Mer 179: 56-61

Bayne, B. L., Widdows, J., Moore, M. N., Salkeld, P., Worrall, C. M., Donkin, P. (1982). Some ecological consequences of the physiological and biochemical effects of petroleum compounds on marine molluscs. Phil. Trans. R. Soc. (Ser. B) 297: 219-239

Bryan, G. W., Hummerstone, L. G. (1973). Adaptation of the polychaete Nereis diversicolor to manganese in estuarine sediments. J. mar biol. Ass. U.K. 53: 859-872

George, S. G. (1983a). Heavy metals detoxication in the mussel Mytilus edulis. Composition of Cd-containing kidney granules (tertiary lysosomes). Comp. Biochem. Physiol. $76 \mathrm{C}: 53-57$ 
George, S. G. (1983b). Heavy metal detoxication in Mytilus kidney. An in vitro study of $\mathrm{Cd}$ and $\mathrm{Zn}$-binding to isolate tertiary lysosomes. Comp. Biochem. Physiol. 76C: 59-65

Goldberg, E. D. (1980). The international mussel watch. National Academy of Sciences, Washington, D.C.

Goldberg, E. D. (1986). The mussel watch concept. Envir Monitor. Assessm. 7: 91-103

Graham, D. L. (1972). Trace metal levels in intertidal mollusks of California. Veliger 14:365-372

Ma, S. W. Y., Shami, Y., Messer, H. H., Copp, D. H. (1974) Properties of $\mathrm{Ca}^{-+}$-ATPase from the gill or rainbow trout (Salmo gairdneri). Biochim. Biophys. Acta 345: 243-251

Mauri, M., Orlando, E. (1982). Experimental study on renal concretions in the wedge shell Donax trunculus L. J. exp. mar. Biol. Ecol. 63: $4 \overrightarrow{7}-57$

Okazaki, R. K. (1976). Copper toxicity in the Pacific oyster Crassostrea gigas. Bull. envir. Contam. Toxicol. 16 658-664

Phillips, D. J. H. (1976). The common mussel Mytilus edulis as an indicator of pollution by zinc, cadmium, lead and copper I. Effects of environmental variables on uptake of metals. Mar. Biol. 38: 59-69

Pringle, B. H., Hissong, D. E., Katz, E. L., Mulawka, S. T (1968). Trace metal accumulation by estuarine molluscs J. sanit. Engng. Div. Am. Soc. civ. Engrs 94: 455-575

Reddy, R. S., Jinna, R. R., Uzodinma, J. E., Desaiah, D. (1988). In vitro effect of mercury and cadmium on brain $\mathrm{Ca}^{2+}$. ATPase of the catfish Ictalurus punctatus. Bull. envir. Contam. Toxicol. 41. 324-328

Schulz-Baldes, M. (1974). Lead uptake from seawater and food, and lead loss in the common mussel Mytilus edulis. Mar. Biol. 25: 177-193

Shephard, K., Simkiss, K. (1978). The effect of heavy metal

This article was presented by S. Bonotto, Mol, Belgium ions on $\mathrm{Ca}^{2+}$-ATPase extracted from fish gills. Comp. Biochem. Physiol. 61B: 69-72

Viarengo, A., Mancinelli, G., Martino, G., Pertica, M., Canesi, L., Mazzucotelli. G. (1988a). Integrated stress indices in heavy metal contamination: their application in a field study. Mar. Ecol. Prog. Ser. 4: 65-70

Viarengo, A., Mancinelli, G., Orunesu, M., Martino, G., Faranda, F., Mazzucotelli, A. (1988b). Effects of sublethal copper concentrations, temperature, salinity and oxygen levels on calcium content and on cellular distribution of copper in the gills of Mytilus galloprovincialis Lam.: a multifactorial experiment. Mar environ. Res. 24: 227-231

Viarengo, A., Palmero, S., Zanicchi, G., Capelli, R, Vaissiere, R., Orunesu, M. (1985). Role of metallothioneins in Cu and $\mathrm{Cd}$ accumulation and elimination in the gill and digestive gland of Mytilus galloprovincialis Lam. Mar. environ. Res. 16: $23-36$

Viarengo, A., Pertica, M., Mancinelli, G., Zanicchi, G., Bouquegneau, J. M., Orunesu, M. (1984). Biochemical characterization of copper-thioneins isolated from the tissues of mussels exposed to the metal. Molec. Physiol. 5: 41-52

Widdows, J., Bayne, B. L., Donkin, P., Livingstone, D. R. Lowe, D. M., Moore, M. N., Salkeld, P. N. (1981). Measurement of the responses of mussels to environmental stress and pollution at Sullom Voe: a base-line study. Proc. R Soc. Edinb. 80B: 323-383

Windom, H. L., Smith, R. G. (1972). The distribution of iron, magnesium, copper, zinc and silver in oysters along the Georgia coast. J. Fish. Res. Bd Can. 29: 450-459

Zhang, G. H., Yamaguchi, M., Kimura, S., Higham, S., KrausFriedmann, N. (1990). Effects of heavy metals on rat liver microsomal $\mathrm{Ca}^{2+}-\mathrm{ATP}$ ase and $\mathrm{Ca}^{2+}$ sequestering. J biol Chem. 265: 2184-2189

Manuscript first received: February 22, 1991

Revised version accepted: May 31, 1991 